\title{
EKSISTENSI BPSK (BADAN PENYELESAIAN SENGKETA KONSUMEN) DALAM PENGAWASAN PENCANTUMAN KLAUSULA BAKU DALAM SISTEM HUKUM PERLINDUNGAN KONSUMEN INDONESIA
}

\author{
THE EXISTENCE OF BPSK (CONSUMER DISPUTE \\ SETTLEMENT BODY) IN THE SUPERVISION OF THE \\ STANDARD CLAUSE IN INDONESIAN CONSUMER \\ PROTECTION LAW SYSTEM
}

\author{
Deviana Yuanitasari \\ Fakultas Hukum Universitas Padjadjaran, Bandung \\ email : deviana.yuanitasari@unpad.ac.id \\ Hazar Kusmayanti \\ Fakultas Hukum Universitas Padjadjaran, Bandung \\ email : hazar.kusmayanti@unpad.ac.id
}

\begin{abstract}
The purpose of this study is to find out, understand and analyze the role of the Consumer Dispute Settlement Agency in supervising the inclusion of standard clauses by businesses in consumer protection law practices and to find out, understand and analyze the sanction procedures and effectiveness of sanctions for business actors that include standard clauses that are prohibited in the consumer protection legal system in Indonesia. This research is a Normative Legal Research and Analytical Descriptive. The results showed that BPSK (Consumer Dispute Settlement Body) was assigned to oversee the inclusion of standard clauses, in addition to resolving consumer disputes, but $B P S K$ was passive and only acted if there were complaints or complaints from consumers. BPSK also does not feel authorized to take action on the inclusion of prohibited standard clauses. BPSK only acts when there are complaints or disputes between business actors and consumers, which is limited to asking business actors to delete the prohibited clause. Although the UUPK states that the prohibited Standard Clause is null and void by law and requires the performer to revoke it, BPSK states that it can only ask violators to revoke the violating clause. Procedure for sanctions and effectiveness of sanctions for business actors that include prohibited standard clauses in the consumer protection legal system in Indonesia is that even though according to Article 52 of the UUPK, BPSK has the right to supervise, but violations of the provisions of the standard clause are not included in BPSK's competence to impose administrative sanctions as regulated in Article 60 of the UUPK. Thus, violations of the provisions of the standard clause cannot be subject to administrative sanctions by BPSK, therefore it is clear that arrangements regarding the sanction procedure are ineffective.
\end{abstract}

Keywords: consumer, standard clause, consumer dispute settlement body.

\begin{abstract}
Abstrak
Tujuan dari penelitian ini adalah untuk mengetahui, memahami dan menganalisis peranan Badan Penyelesaian Sengketa Konsumen dalam melakukan pengawasan terhadap pencantuman klausula baku oleh pelaku usaha dalam praktik hukum perlindungan konsumen dan untuk mengetahui, memahami dan menganalisis
\end{abstract}


mengenai prosedur sanksi dan efektifitas sanksi tersebut bagi pelaku usaha yang mencantumkan klausula baku yang dilarang dalam sistem hukum perlindungan konsumen di Indonesia. Penelitian ini merupakan Penelitian Hukum Normatif dan bersifat Deskriptif Analitis.Hasil penelitian menunjukkan bahwa BPSK ditugaskan untuk mengawasi pencantuman klausula baku, selain menyelesaikan sengketa konsumen, namun BPSK bersifat pasif dan hanya bertindak jika ada pengaduan atau keluhan konsumen. BPSK juga tidak merasa berwenang menindak pencantuman klausula baku yang dilarang. Tindakan BPSK hanya pada saat ada pengaduan atau sengketa antara pelaku usaha dengan konsumen yaitu sebatas meminta pelaku usaha untuk menghapus klausula yang diarang.Meski UUPK menyatakan Klausula Baku terlarang batal demi hukum dan mewajibkan pelaku usaha pencantum untuk mencabutnya namun BPSK menyatakan hanya bisa meminta pelanggar untuk mencabut klausula yang melanggar itu.Prosedur sanksi dan efektifitas sanksi tersebut bagipelaku usaha yang mencantumkan klausula baku yang dilarang dalam sistem hukum perlindungan konsumen di Indonesiaadalah walaupun menurut Pasal 52 UUPK, BPSK berhak melakukan pengawasan, namun pelanggaran terhadap ketentuan klausula baku, tidak termasuk dalam kompetensi BPSK untuk menjatuhkan sanksi administrasi sebagaimana diatur dalam Pasal 60 UUPK. Dengan demikian, pelanggaran terhadap ketentuan klausula baku tidak dapat dikenakan sanksi administrasi oleh BPSK, sehingga jelas pengaturan mengenai prosedur sanksi tersebut menjadi tidak efektif

\section{Kata Kunci : konsumen, klausula baku, BPSK}

\section{PENDAHULUAN}

Perkembangan dunia perdagangan di era revolusi industri 4.0 saat ini yang menuntut semua serba cepat menjadikan kebutuhan terhadap perjanjian-perjanjian yang bersifat praktis dan siap saji semakin meningkat.Peraturan-peraturan baru juga berkembang dengan pesat di seluruh dunia saat ini dikarenakan jenis transaksi juga semakin berkembang. ${ }^{1}$ Perjanjian Baku saat ini merupakan kenyataan yang tidak dapat dihindari. Bagi perusahaan atau pelaku usaha, pembakuan syarat-syarat dalam perjanjian merupakan salah satu cara untuk mencapai tujuan ekonomi yang efisien, praktis dan cepat. Di sisi lain, bagi konsumen justru ini merupakan pilihan yang tidak menguntungkan. Contoh perjanjian baku antara lain : perjanjian jual beli, polis asuransi, kredit dengan jaminan. Sedangkan dokumen atau bukti perjanjian baku terdapat dalam konosemen, nota pesan, nota pembelian, tiket/karcis dan lain-lain. ${ }^{2}$

Di Indonesia, Undang-Undang No. 8 Tahun 1999 tentang Perlindungan Konsumen (selanjutnya disebut UUPK) menjadi landasan hukum bagi bagi upaya pemberdayaan konsumen, diharapkan dapat mengantar konsumen Indonesiamenjadi konsumen mandiri yang juga paham akan hak dan kewajibannya, UUPK bukan hanya sekedar kebijakan legislasi bagi upaya perlindungan konsumen, tetapi juga bagi upaya menegakkan etika bisnis di kalangan pelaku usaha. ${ }^{3}$ Perlindungan hukum terhadap konsumen pada dasarnya merupakan perlindungan terhadap pemenuhan atas hak-hak konsumen yang seharusnya diberikan kepada konsumen. ${ }^{4}$

Syarat dalam perjanjian baku pada umumnya ditentukan secara sepihak oleh pelaku usaha. Rumusan syarat yang dimaksud biasanya dibuat secara rinci dalam format/ sistem

${ }^{1}$ Elena Kirillova et al, The Principles of the Consumer Right Protection in Electronic Trade: A Comparative Law Analysis, International Journal of Economics and Financial Issues, 2016, 6(S2) 117-122.

${ }_{2}$ Pemberdayaan Hak-Hak Konsumen di Indonesia, Direktorat Perlindungan Konsumen Ditjen Perdagangan Dalam Negeri, Departemen Perindustrian Dan Perdagangan,2001, Hlm 191.

${ }^{3}$ Deviana Yuanitasari, Re-Evaluasi Penerapan Doktrin Caveat Venditor dalam Tanggung Jawab Pelaku Usaha terhadap Konsumen, Jurnal Arena Hukum, Vol 10 No. 3 Tahun 2017, Hlm 425

${ }^{4}$ Susilowati Suparto, Djanuardi, et al, Harmonisasi dan Sinkronisasi Pengaturan Kelembagaan Sertifikasi Halal Terkait Perlindungan Konsumen Muslim Indonesia, Jurnal Mimbar Hukum, Vol 28, No.3 Tahun 2016, Hlm. 428 
penomoran, pasal-pasal atau secara singkat memuat klausula tertentu yang bertujuan melindungi kepentingan pihak pelaku usaha. Adakalanya syarat tersebut dibuat dengan susunan huruf yang amat kecil dan padat, sehingga menimbulkan kesulitan bagi konsumen untuk memahaminya dalam waktu singkat

Klausula baku sebagaimana telah dijelaskan sebelumnya memiliki banyak istilah lain dalam penyebutannya, istilah tersebut antara lain ${ }^{5}$ :

a. Standart Contract (Bahasa Inggris)

b. Standardized Contract (Bahasa Inggris)

c. Algemene Voorwaarden (Bahasa Belanda)

d. Standaarverrag (Bahasa Jerman)

e. Perjanjian Standar (Bahasa Indonesia).

Pengertian klausula baku selain dalam UU Perlindungan Konsumen juga banyak dikemukakan oleh para ahli. Menurut Mariam Darus Badrulzaman yang mendefinisikan perjanjian standar sebagai perjanjian yang isinya dibakukan dan dituangkan dalam bentuk formulir.

Klausula baku pada dasarnya potensial sekali merugikan konsumen karena konsumen tak memiliki pilihan selain menerimanya. Namun di sisi lain, harus diakui pula klausula baku sangat membantu kelancaran perdagangan. Sulit membayangkan jika dalam banyak perjanjian atau kontrak sehari-hari kita selalu harus menegosiasikan syarat dan ketentuannya. Misalnya jika membeli tiket menonton pertunjukan, tidak mungkin pelaku usaha dan konsumen harus menegosiasikan terlebih dahulu mengenai hak dan kewajiban masing-masing pihak dan mengenai akibat hukumnya apabila kemudian pertunjukan tersebut dibatalkan. Namun demikian, untuk melindungi kepentingan konsumen beberapa jenis klausula baku secara tegas dilarang dalam UUPK. Jika pelaku usaha tetap mencantumkan klausula baku yang dilarang tersebut, maka klausula itu batal demi hukum. Artinya, klausula itu dianggap tidak pernah ada.

Dalam sistem hukum perlindungan konsumen di Indonesia, Badan Penyelesaian Sengketa Konsumen (Selanjutnya disebut BPSK) ditugaskan untuk mengawasi pencantuman klausula baku, selain menyelesaikan sengketa konsumen. Isi Pasal Pasal 52 UUPK yaitu : Tugas dan wewenang badan penyelesaian sengketa konsumen meliputi : c. melakukan pengawasan terhadap pencantuman klausula baku; Meski menurut Pasal 52 UUPK, BPSK berhak melakukan pengawasan, namun pelanggaran terhadap ketentuan klausula baku, tidak termasuk dalam kompetensi BPSK untuk menjatuhkan sanksi administrasi sebagaimana diatur dalam Pasal 60 UUPK. Dengan demikian, pelanggaran terhadap ketentuan klausula baku tidak dapat dikenakan sanksi administrasi oleh BPSK.

Tujuan dari penelitian ini adalah untuk menganalisis dan merumuskan Peranan Badan Penyelesaian Sengketa Konsumen dalam melakukan pengawasan terhadap pencantuman klausula baku oleh pelaku usaha dalam praktik hukum perlindungan konsumen dan untuk merumuskan prosedur sanksi dan efektifitas sanksi tersebut bagi pelaku usaha yang mencantumkan klausula baku yang dilarang dalam sistem hukum perlindungan konsumen di Indonesia.

Penulisan hukum ini menggunakan metode pendekatan yuridis normatif yaitu penelitian dititik beratkan pada penggunaan data sekuder, yang mencakup bahan hukum primer, sekunder dan tersier. Penelitian dilakukan dengan meneliti ketentuan-

\footnotetext{
${ }^{5}$ Munir Fuadi, 2007, Hukum Kontrak (Dari Sudut Pandang Hukum Bisnis), Citra Aditya Bakti, Bandung, hlm 75.
} 
ketentuan mengenai konsep pencantuman klausula baku dalam kontrak baku dikaitkan dengan ketentuan Undang-Undang Perlindungan Konsumen.

\section{PEMBAHASAN}

\section{Peranan Badan Penyelesaian Sengketa Konsumen Dalam Melakukan Pengawasan Terhadap Pencantuman Klausula Baku Oleh Pelaku Usaha Dalam Praktik Hu- kum Perlindungan Konsumen di Indonesia}

Di dalam perkembangannya, kebebasan berkontrak hanya bisa mencapai tujuannya bila para pihak mempunyai bargaining position yang seimbang. Jika salah satu pihak lemah maka pihak yang memiliki bargaining position lebih kuat dapat memaksakan kehendaknya untuk menekan pihak lain, demi keuntungannya sendiri. Syarat-syarat dalam kontrak yang semacam itu akhirnya akan melanggar aturan-aturan yang adil dan layak. Di dalam kenyataannya, para pihak yang saling berhubungan tidak selalu memiliki bargaining position yang seimbang, sehingga dalam hal inilah diperlukan campur tangan negara untuk melindungi pihak yang lemah. ${ }^{6}$

Dalam sistem hukum Indonesia, ternyata tidak ada pengaturan jelas tentang adanya larangan perjanjian baku ini. Tetapi hukum Indonesia jelas-jelas melarang klausula baku tertentu sebagaimana hal itu diatur tegas dalam Undang-Undang No 8 tahun 1999 tentang Perlindungan Konsumen. Namun tidak semua klausula baku dilarang dalam perjanjian, hanya beberapa klasula baku yang memenuhi kualifikasi yang ditetapkan oleh Undang-Undang No 8 tahun 1999. Pembuat undang-undang ternyata membedakan antara perjanjian baku dengan klausula baku. Undang-Undang tidak memberikan definisi perihal klausula baku. Penjelasan Pasal 18 yang melarang klausula baku juga tidak menjelaskan. Oleh karena itu, pengertian klausula baku dapat menggunakan pengertian sebagaimana berkembang dalam dunia praktik bisnis. Klausula baku adalah setiap syarat dan ketentuan yang telah disiapkan dan ditetapkan terlebih dahulu secara sepihak oleh pengusaha yang dituangkan dalam suatu dokumen atau perjanjian yang mengikat dan wajib dipenuhi oleh konsumen. ${ }^{7}$

Oleh karena itu setiap klausula baku pasti merupakan bagian dari perjanjian baku. Sebab dalam perjanjian baku ada klausula-klausula yang telah dibakukan dalam sisi perjanjian baku tersebut. Isi yang telah dibakukan tersebut merupakan klausula-klausula yang telah dibakukan yang dikenal dengan klausula baku. Perjanjian baku merupakan wadah atau tempat sedangkan klausula baku merupakan bagian yang mengisi wadah atau tempat tersebut. Oleh karena itu, Pembahasan klausula juga tidak dapat dilepaskan dari perjanjian.

Dalam sistem Hukum Perdata Indonesia, perikatan dapat timbul dari dua hal, yaitu pertama dari perjanjian dan kedua yaitu yang timbulnya karena undang-undang. Perikatan diartikan sebagai hubungan hukum antara dua orang atau dua pihak, berdasarkan mana pihak yang satu berhak menuntut sesuatu hak dari pihak yang lain ( pemenuhan prestasi) dan pihak yang lain berkewajiban untuk memenuhi tuntutan itu (kontra prestasi).Hukum perjanjian dalam KUH Perdata menganut asas konsensualisme. Konsensualisme berasal dari akar kata konsensus yang berarti sepakat. Kesepakatan

\footnotetext{
${ }^{6}$ Sutan Remy Sjahdeini, 1993. Kebebasan Berkontrak dan Perlindungan Yang Seimbang Bagi Para Pihak Dalam Perjanjian Kredit Bank di Indonesia, Jakarta Penerbit IBI, hlm 8.

${ }^{7}$ Undang-Undang Nomor 8 Tahun 1999 tentang Perlindungan Konsumen
} 
dapat berupa suatu perjanjian tertulis, atau lisan atau kebiasaan yang terjadi dalam satu sifat atau lingkup transaksi tertentu.

Pihak yang berhak menuntut prestasi (kreditur) mendapatkan perlindungan hukum untuk meminta pemenuhan, atau pemulihan atau ganti rugi dalam hal pihak yang harus memenuhi prestasi (debitur) dalam keadaan tidak dapat (baik karena tidak mampu atau sebab lainnya) memenuhi prestasi dimaksud. Perjanjian pada umumnya bersifat bilateral dan timbal balik, artinya suatu pihak yang memperoleh hak-hak dari perjanjian itu, juga menerima kewajiban-kewajiban yang merupakan kebalikan dari hak hak yang diperolehnya. Sebaliknya suatu pihak yang memikul kewajiban kewajiban juga memperoleh hak-hak yang dianggap merupakan kebalikan dari kewajiban yang dibebankan padanya.

Sehubungan dengan masalah perlindungan konsumen, perlindungan hukum bagi konsumen diwujudkan dalam bentuk penghargaan hak-hak dari konsumen, diwujudkannya kewajiban pelaku usaha, adanya batasan bagi pelaku usaha baik dalam perbuatan tertentu yang dilarang, maupun pelarangan pencantuman klausula baku tertentu, perwujudan tanggung jawab pelaku usaha, serta upaya penyelesaian sengketa perlindungan konsumen.

Kesadaran konsumen akan haknya yang masih rendah, ditunjang oleh tingkat pendidikan konsumen sendiri menjadi pemicu pentingnya perlindungan konsumen. Perlindungan konsumen diartikan cukup jelas, yang terwujud dalam perkataan, segala upaya yang menjamin adanya kepastian hukum untuk memberikan perlindungan kepada konsumen. Pengertian tersebut diparalelkan dengan definisi konsumen yaitu : setiap orang pemakai barang dan/atau jasa yang tersedia di masyarakat, baik bagi kepentingan diri sendiri, keluarga, orang lain maupun makhluk hidup lain dan tidak untuk diperdagangkan. ${ }^{8}$

Pasal 1 angka 1 UUPK menyebutkan bahwa :

"Perlindungan Konsumen adalah segala usaha yang menjamin adanya kepastian hukum untuk memberik perlindungan kepada konsumen"

Menurut Hans W. Mikclitz ${ }^{9}$ dalam perlindungan konsumen secara garis besar dapat ditempuh dua model kebijakan, yaitu :

a. Kebijakan yang bersifat komplementer, yaitu kebijakan yang mewajibkan pelaku usaha memberikan informasi yang memadai kepadakonsumen (hak atas informasi);

b. Kebijakan kompensatoris, yaitu kebijakan yang berisikan perlindungan terhadap kepentingan ekonomi konsumen (hak atas kesehatan dan keamanan).

Selain ditinjau dari bidang-bidang hukum yang mengatur perihal perlidungan konsumen dan dua macam kebijakan umum yang dapat ditempuh, juga terdapat prinsipprinsip pengaturan di bidang perlindungan konsumen. UUPK menyebutkan lima prinsip pengaturan yang dikaitkan dengan asas-asas pembangunan nasional, yaitu asas manfaat, keadilan, keseimbangan, keamanan dan keselamatan, serta kepastian hukum. ${ }^{10}$

Kebebasan berkontrak adalah kebebasan para pihak yang terlibat dalam suatu perjanjian untuk dapat menyusun dan menyetujui klausul-klausul dari perjanjian tersebut, tanpa campur tangan pihak lain. Campur tangan tersebut datang dari negara melalui peraturan perundang-undangan yang menetapkan ketentuan-ketentuan yang diperkenankan atau dilarang. Campur tangan tersebut dapat pula datangnya dari pihak

\footnotetext{
${ }^{8}$ Shidarta, 2004. Hukum Perlindungan Konsumen, Gramedia, Jakarta, hlm.5

${ }^{9}$ Hans W. Micklitz, dalam Sidharta, Ibid.., hal. 49.

${ }^{10}$ Untuk lebih jelasnya lihat ketentuan Pasal 2 UUPK.
} 
pengadilan, berupa putusan pengadilan yang membatalkan suatu klausul dari suatu perjanjian atau seluruh perjanjian itu, berupa putusan yang berisi pernyataan bahwa suatu perjanjian batal demi hukum. ${ }^{11}$

Klausula Baku dalam UUPK Pasal 1 Angka (10), didefinisikan sebagai setiap aturan atau ketentuan dan syarat-syarat yang dipersiapkan dan ditetapkan terlebih dahulu secara sepihak oleh pelaku usaha yang dituangkan dalam suatu dokumen dan/atau perjanjian yang mengikat dan wajib diikuti oleh konsumen. ${ }^{12}$ Perjanjian Baku adalah perjanjian yang didalamnya dibakukan syarat (klausula) eksonerasi dan dituangkan dalam bentuk formulir dimana pihak yang lemah biasanya konsumen, tidak memiliki daya tawar untuk merundingkan perubahan. Klausula Eksonerasi adalah klausula yang mengandung kondisi membatasi, atau bahkan menghapus sama sekali tanggung jawab yang semestinya dibebankan kepada pihak produsen/penyalur produk (penjual).

Sebagaimana telah dijelaskan di awal bahwa tidak ada pengaturan jelas perihal larangan perjanjian baku. Namun, ada pengaturan tegas adanya larangan klausula baku tetapi tidak semua perjanjian baku dilarang. Undang-Undang No 8 Tahun 1999 hanya melarang klausula baku dengan kualifikasi sebagai berikut

a. Pengalihan tanggungjawab dari pelaku usaha (atau pengusaha) kepada konsumen

b. Hak pengusaha untuk menolak mengembalikan barang yang dibeli konsumen

c. Hak pengusaha untuk menyerahkan uang yang dibayarkan atas barang atau jasa yang dibeli oleh konsumen

d. Pemberian kuasa dari konsumen kepada pengusaha untuk melakukan segala tindakan sepihak berkaitan dengan barang yang dibeli secara angsuran

e. Mengatur perihal pembuktian atas hilangnya kegunaan barang atau pemanfaatan jasa yang dibeli konsumen

f. Hak pengusaha untuk mengurangi manfaat jasa atau mengurangi harta kekayaan konsumen yang menjadi obyek jual beli jasa

g. Tunduknya konsumen kepada peraturan yang berupa aturan baru, tambahan atau lanjutan yang dibuat sepihak oleh pengusaha semasa konsumen memanfaatkan jasa yang dibelinya

h. Pemberian kuasa kepada pengusaha untuk pembebanan hak tanggungan, gadai, atau hak jaminan terhadap barang yang dibeli oleh konsumen secara angsuran

Selain itu, pengusaha juga dilarang mencantumkan klausula baku yang letak atau bentuknya sulit terlihat atau tak dapat jelas dibaca, atau yang maksudnya sulit dimengerti. Jika pengusaha tetap mencantumkan klausula baku yang dilarang tersebut, maka klausula itu batal demi hukum yang berarti bahwa klausula itu dianggap tidak pernah ada. Apabila disimak pengaturan Undang-Undang Perlindungan Konsumen, maka pelanggaran terhadap klausula baku sebagaimana ditetapkan oleh ayat 1 dan ayat 2 pasal 18 UUPK maka mengakibatkan perjanjian tersebut batal demi hukum.

Dalam sistem hukum perlindungan konsumen Indonesia yang bertugas untuk mengawasi pencantuman klausula baku oleh pelaku usaha adalah Badan Penyelesaian Sengketa Konsumen (BPSK). BPSK ditugaskan untuk mengawasi pencantuman klausula baku, selain menyelesaikan sengketa konsumen. Namun, BPSK bersifat pasif dan hanya bertindak jika ada pengaduan atau keluhan konsumen. BPSK tidak merasa berwenang menindak pencantuman klausula baku yang dilarang. Tindakah BPSK

\footnotetext{
${ }^{11}$ Sutan Remi Sjahdeini, Op. Cit..hal. 11.

${ }^{12}$ Pasal 1 angka (10) Undang-Undang No. 8 Tahun 1999 tentang Perlindungan Konsumen
} 
sebatas meminta pelaku usaha untuk menghapus klausula yang dilarang itu jika timbul sengketa. Meski UUPK menyatakan Klausula Baku terlarang batal demi hukum dan mewajibkan pelaku usaha pencantum untuk mencabutnya namun BPSK menyatakan hanya bisa meminta pelanggar untuk mencabut klausula yang melanggar itu. Sementara penyidik Kementerian Perdagangan(Kemendag) pun belum pernah mengambil langkahrepresif bagi pelanggar.

\section{Prosedur Sanksi dan Efektifitas Sanksi Tersebut Bagi Pelaku Usaha Yang Men- cantumkan Klausula Baku Yang Dilarang Dalam Sistem Hukum Perlindungan Konsumen di Indonesia.}

Dalam rangka kepentingan bisnis dan efisiensi banyak sekali pelaku bisnis yang membakukan perjanjian yang dibuat. Perjanjian baku dimaksudkan untuk membuat keseragaman ukuran pelaku usaha dalam menjalankan usahanya. Perjanjian baku ini tentu telah dipersiapkan sebelumnya oleh pelaku usaha dan telah ditetapkan secara sepihak isinya. Namun, pelaku usaha tetap meminta persetujuan dari pihak lain yang diajak bertransaksi atas perjanjian baku yang diadakan oleh pelaku usaha tersebut. Memang klausula baku potensial merugikan konsumen karena tak memiliki pilihan selain menerimanya. Namun di sisi lain, harus diakui pula klausula baku sangat membantu kelancaran perdagangan. Sulit membayangkan jika dalam banyak perjanjian atau kontrak sehari-hari kita selalu harus menegosiasikan syarat dan ketentuannya. Dalam pustaka hukum, perjanjian baku juga dikenal dengan sebutan standardized agreement, standard contract atau contract of adhesion.

Pada dasarnya perjanjian dibuat oleh pihak-pihak yang kedudukannya seimbang, apabila yang merancang perjanjian adalah pihak yang memiliki kedudukan lebih kuat, maka dapat dipastikan perjanjian tersebut memuat klausula-klausula yang menguntungkan baginya, atau meringankan atau menghapuskan beban-beban atau kewajiban yang seharusnya menjadi tanggung jawabnya. ${ }^{13}$ Perjanjian baku merupakan suatu bentuk perjanjian yang secara teoritis masih mengandung perdebatan. ${ }^{14}$ Menurut Pasal 18 UUPK terdapat larangan mencantumkan klausula-klausula tertentu dalam perjanjian yang bertujuan untuk melindungi konsumen ${ }^{15}$. Faktanya klausula baku yang dilarang tersebut hingga saat ini masih dicantumkan oleh pelaku usaha tanpa adanya sanksi yang dikenakan. Hal ini antara lain dipengaruhi oleh sikap konsumen terhadap keberadaan klausula baku, ketaatan pelaku usaha terhadap aturan, dan ketegasan aparatur negara dalam menegakkan aturan dan sanksi. ${ }^{16}$

BPSK merupakan badan yang dibentuk oleh Pemerintah di Daerah Tingkat II untuk penyelesaian sengketa konsumen di luar pengadilan. Berdasarkan Pasal 53 Undang-Undang Perlindungan Konsumen menyatakan bahwa pelaksanaan tugas dan wewenang BPSK Daerah Tingkat II diatur dalam surat keputusan menteri. Adapun keputusan menteri yang mengatur mengenai pelaksanaan kerja BPSK yaitu Keputusan Menteri Perindustrian dan Perdagangan No. 350 Tahun 2001 tentang Pelaksanaan Tugas dan Wewenang Badan Penyelesaian Sengketa Konsumen (selanjutnya disebut KEPMENPERINDAG No. 350/2001).

\footnotetext{
${ }^{13}$ Ahmadi Miru \& Sutarman Yodo, 2014, Hukum Perlindungan Konsumen, PT. Raja Grafindo Persada Jakarta, hlm 15

${ }^{14}$ Zulham, 2013, Hukum Perlindungan Konsumen, Jakarta : PT. Kencana Prenada Media Group, hlm 76

${ }^{15}$ Miru \& Yodo, Op Cit, hlm 151

16 David Tobing, Konsumen dan Klausula Baku, http://bpkn.go.id/uoloads/documents/6ac89beeea3fodc87095541b652395208ebd4dc.pdf
} 
Salah satu kewenangan BPSK sebagaimana tercantum dalam Pasal 52 huruf c Undang-Undang Perlindungan Konsumen adalah melakukan pengawasan terhadap pencantuman klausula baku. Ketentuan ini diperjelas oleh aturanpelaksanaannya yaitu dalam Pasal 3 hurf c KEPMENPERINDAG No. 350/2001 menyatakan bahwa BPSK memiliki tugas dan wewenang dalam melakukan pengawasan terhadap klausula baku, serta pada Pasal 9 KEPMENPERINDAG No. 350/2001) menyebutkan bahwa :

1) pengawasan terhadap pencantumanklausulabaku, sebagaimana dimaksud dalam Pasal 3 huruf c, dilakukan oleh BPSK dengan atau tanpa pengaduan dari konsumen.

2) hasil pengawasan pencantuman klausula baku sebagaimana dimaksud dalam ayat (1) yang membuktikan adanya pelanggaran terhadap larangan pencantuman klausula baku di dalam Undang-Undang Perlindungan konsumen, diberitahukan secara tertulis kepada pelaku usaha sebagai peringatan.

3) peringatan tertulis sebagaimana dimaksud dalam ayat (2) dilakukan tiga kali berturutturut dengan tenggang waktu untuk masing-masing peringatan satu bulan.

4) bilamana pelaku usaha tidak mengindahkan peringatan tertulis sebagaimana dimaksud dalam ayat (3), maka BPSK melaporkan kepada Penyidik Pegawai Negeri Sipil (PPNS) yang ruang lingkup tugas dan tanggung jawabnya di bidang perlindungan konsumen untuk dilakukan penyidikan dan prosespenuntutansesuai denganketentuan peraturan yang berlaku.

Aturan KEPMENPERINDAG No. 350/2001 tersebut jelas menyebutkan bahwa BPSK dapat melakukan pengawasan terhadap klausula baku dengan atau tanpa pengaduan dari konsumen. Artinya BPSK dapat secara aktif melakukan pengawasan terhadap pencantuman klausula baku. Tetapi dalam praktiknya BPSK lebih berperan pasif.Pengawasan pencantuman klausula baku yang dilakukan oleh BPSK sampai saat ini hanya menunggu pengaduan dari konsumen. Jika ada konsumen yang melakukan pengaduan terkait dengan pencantuman klausula baku, maka pelaku usaha akan dipanggil oleh BPSK dengan memberikan surat pemanggilan. Sanksi yang diberikan BPSK kepada pelaku usaha yang mencantumkan klausula baku tersebut hanya sebatas pemberian peringatan dan belum ada tindakan tegas. Pencantuman klausula baku yang dikategorikan melanggar UndangUndang Perlindungan Konsumen sampai dengan saat ini masih banyak ditemukan, baik pada pelaku usaha kecil, menengah maupun besar. Contoh pencantuman klausula baku tersebut oleh pelaku usaha kecil dan menengah biasanya terdapat pada nota pembelian barang. Sedangkan contoh klausula baku pada usaha besar adalah klasula baku pada perjanjian lembaga pembiayaan.

Pengawasan pencantuman klausula baku secara langsung oleh BPSK belum dapat dilaksanakan. BPSK belum berinisiatif melakukan pengawasan langsung ke lapangan karena belum ada pengaturan lebih lanjut mengenai Juklak (Petunjuk Pelaksanaan) tentang pengawasan pencantuman klausula baku. Pengawasan yang dilakukan oleh BPSK hanya sebatas adanya sengketa terkait dengan pencantuman klausula baku, artinya tindakan yang dilakukan oleh BPSK baru akan memproses setelah adanya pengaduan dari konsumen. Salah satu contoh pengawasan klausula baku yang dilakukaan bersamaan dengan adanya sengketa yaitu pada sengketa antara konsumen dengan pelaku usaha penyedia jasa kredit motor. Pada sengketa tersebut biasanya terkait dengan klausula baku yang memberatkan konsumen, sehingga konsumen dirugikan. Pada proses penyelesaian sengketa BPSK mempelajari klausula tersebut apakah klausula-klausula 
yang dicantumkan tersebut tergolong klausula yang dilarang di dalam Undang-Undang Perlindungan Konsumen atau tidak. Jika klausula tersebut tergolong klausula yang dilarang, maka setelah penyelesaian sengketa selesai BPSK akan memberikan sosialisasi atau pembinaan kepada pelaku usaha bahwa klausula tersebut dilarang dan BPSK akan meminta mengganti klausula tersebut. Kemudian BPSK akan melakukan pemeriksaan secara berkala apakah pelaku usaha tersebut masih mencantumkan klausula baku yang dilarang oleh UndangUndang Perlindungan Konsumen atau tidak.

Prosedur sanksi yang diberikan oleh BPSK kepada pelaku usaha yang mencantumkan klasula baku tersebut adalah hanya sebatas memberi peringatan. Sanksi peringatan yang diberikan kepada pelaku yang melanggar ketentuan pencantuman klausula baku yaitu berbentuk peringatan tertulis. Peringatan tersebut diberikan kepada pelaku usaha maksimal sebanyak 3 (tiga) kali dengan tenggang waktu masing-masing peringatan 1 (satu) bulan. Sesuai dengan ketentuan Pasal 9 ayat (4) Surat Keputusan Menteri Perin dustrian dan Perdagangan No. 350/MPP/12/2001 tentang Pelaksanaan Tugas dan Wewenang BPSK, bilamana pelaku usaha tidak mengindahkan peringatan tersebut maka BPSK melaporkan kepada Penyidik Pegawai Negeri Sipil (PPNS) yang ruang lingkup tugas dan tanggung jawabnya di bidang Perlindungan Konsumen untuk dilakukan penyidikan dan proses penuntutan sesuai dengan ketentuan peraturan yang berlaku. Pengawasan pencantuman klausula baku yang dilakukan oleh BPSK dapat dikatakan belum maksimal dan juga dirasa tidak efektif mengingat keberadaan BPSK berada di kabupaten dan kota, sementara klausula baku itu diterapkan oleh satu perusahaan yang berpusat di Jakarta misalnya, dan keberlakuannya di berbagai provinsi bahkan kabupaten kota di Indonesia. Sehingga kalaupun ada satu BPSK yang membatalkan satu klausula baku perusahaan tertentu, maka itu hanya berlaku di kabupaten dan kota tersebut.

Dalam melaksanakan kewenangannya sesuai dengan pasal 52 UndangUndang Nomor 8 Tahun 1999 jo Pasal 3 Kepmenperindag No. 350/MPP/Kep/12/2001, terutama tentang kewenangan mengawasi pencantuman klausula baku dalam pelaksanaannya bukan berarti tidak memiliki hambatan. Kendala yang dialami oleh BPSK dalam melaksanakan kewenangannya mengawasi pencantuman klausula baku yang melanggar Undang-Undang Perlindungan Konsumen sebagai lembaga pengawasan dalam UndangUndang Perlindungan Konsumen, yaitu belum ada aturan lebih lanjut mengenai Juklak (Petunjuk Pelaksanaan) pengawasan dan sanksi yang tegas kepada pelaku usaha yang melanggar ketentuan Undang-Undang Perlindungan Konsumen, sehingga dalam praktiknya, pelaksanaan pengawasan yang dilakukan oleh BPSK menjadi tidak berjalan dengan semestinya. Adanya tumpang tindih aturan mengenai pengawasan pencantuman klausula baku membuat BPSK menjadi dilematis dalam melaksanakan tugas dan wewenangnya. Di dalam Pasal 52 huruf e menyebutkan bahwa tugas dan wewenang BPSK yaitu "menerima pengaduan baik tertulis maupun tidak tertulis dari konsumen tentang terjadinya pelanggaran terhadap perlindungan konsumen". Sedangkan di dalam Pasal 9 ayat (1) Kepmenperindag No. 350/MPP/Kep/12/2001 menyebutkan bahwa "Pengawasan terhadap pencantuman klausula baku, sebagaimana dimaksud dalam Pasal 3 huruf c, dilakukan oleh BPSK dengan atau tanpa pengaduan dari konsumen". Artinya, BPSK seharusnya dapat melakukan pengawasan tanpa menunggu adanya pengaduan dari konsumen.Ketidakpastian peraturan tersebut yang membuat BPSK menjadi dilematis dalam melaksanakan pengawasan pelaksanaannya, sehingga 
menimbulkan ketidakpastian hukum.Dengan tidak adanya aturan lebih lanjut mengenai teknis pelaksanaan pengawasan membuat BPSK ragu dalam melaksanakan kewenangan pengawasan tersebut. Dalam hal pemberian sanksi, Pasal 60 Undang-Undang Nomor 8 Tahun 1999 tentang Perlindungan Konsumen telah diatur mengenai penjatuhan sanksi administratif kepada pelaku usaha yang melanggar ketentuan UndangUndang Perlindungan Konsumen. Namun di dalam praktiknya BPSK tidak dapat melaksanakan sanksi administrasi tersebut kepada pelanggar ketentuan pencantumanklausula baku. Sanksi yang diberikan kepada pelanggar pencantuman klausula baku hanya sebatas memberi peringatan sehingga penulis rasa dalam hal pemberian sanksi ini menjadi tidak efektif.

\section{SIMPULAN}

Peran Badan Penyelesaian Sengketa Konsumen dalam melakukan pengawasan terhadap pencantuman klausula baku oleh pelaku usaha dalam praktik hukum perlindungan konsumen adalah untuk mengawasi pencantuman klausula baku, selain menyelesaikan sengketa konsumen. Namun, BPSK bersifat pasif dan hanya bertindakjika ada pengaduan atau keluhan konsumen. BPSK juga tidak merasa berwenang menindak pencantuman klausula baku yang dilarang. Tindakan BPSK hanya pada saat ada pengaduan atau sengketa antara pelaku usaha dengan konsumen yaitu sebatas meminta pelaku usaha untuk menghapus klausula yang dilarang. Meski UUPK menyatakan Klausula Baku terlarang batal demi hukum dan mewajibkan pelaku usaha pencantum untuk mencabutnya namun BPSK menyatakan hanya bisa meminta pelanggar untuk mencabut klausula yang melanggar itu.

Prosedur sanksi dan efektifitas sanksi tersebut bagipelaku usaha yang mencantumkan klausula baku yang dilarang dalam sistem hukum perlindungan konsumen di Indonesiaadalah walaupun menurut Pasal 52 UUPK, BPSK berhak melakukan pengawasan, namun pelanggaran terhadap ketentuan klausula baku, tidak termasuk dalam kompetensi BPSK untuk menjatuhkan sanksi administrasi sebagaimana diatur dalam Pasal 60 UUPK. Dengan demikian, pelanggaran terhadap ketentuan klausula baku tidak dapat dikenakan sanksi administrasi oleh BPSK, sehingga jelas pengaturan mengenai prosedur sanksi tersebut menjadi tidak efektif.

\section{DAFTAR PUSTAKA}

\section{Buku}

Ahmadi Miru \& Sutarman Yodo, (2014), Hukum Perlindungan Konsumen, PT. Raja Grafindo Persada,Jakarta.

Direktorat Perlindungan Konsumen, (2001), Pemberdayaan Hak-hak Konsumen di Indonesia, Dirjen Perdagangan Dalam Negeri, Departemen Perindustrian dan Perdagangan, Jakarta.

Direktorat Perlindungan Konsumen, (2001), Pedoman Klausula Baku di Bidang Perbankan yang Disempurnakan, Dirjen Perdagangan Dalam Negeri, Departemen Perindustrian dan Perdagangan, Jakarta.

Mariam Darus Badruldjaman, (1962), Keputusan-keputusan Tentang Perkara Perdata, Bapit Cabang Sumatera Utara, Medan.

Ronny Hanitijo Soemitro, (1988), Metodologi Penelitian Hukum dan Jurimetri, Ghalia 
Indonesia, Jakarta.

R. Setiawan, (1978), Pokok-Pokok Hukum Perikatan, Bina Cipta,Bandung.

Shidarta, (2004), Hukum Perlindungan Konsumen, Gramedia, Jakarta.

Sutan Remy Sjahdeini, (1993), Kebebasan Berkontrak dan Perlindungan Yang Seimbang Bagi Para Pihak Dalam Perjanjian Kredit Bank di Indonesia, Penerbit IBI,Jakarta.

Yusuf Shofie,(2003), Perlindungan Konsumen dan Instrumen-instrumen Hukumnya, Citra Aditya Bakti, Bandung.

Zulham, (2013), Hukum Perlindungan Konsumen, PT. Kencana Prenada Media Group, Jakarta.

\section{Artikel Ilimiah}

Deviana Yuanitasari, Re-Evaluasi Penerapan Doktrin Caveat Venditor dalam Tanggung Jawab Pelaku Usaha terhadap Konsumen, Jurnal Arena Hukum, Vol 10 No. 3 Tahun 2017425

Elena Kirillova et al, The Principles of the Consumer Right Protection in Electronic Trade: A Comparative Law Analysis, International Journal of Economics and Financial Issues, 2016, 6(S2) 117-122

Susilowati Suparto, Djanuardi, et al, Harmonisasi dan Sinkronisasi Pengaturan Kelembagaan Sertifikasi Halal Terkait Perlindungan Konsumen Muslim Indonesia, Jurnal Mimbar Hukum, Vol 28, No.3 Tahun 2016, Hlm. 428

\section{Peraturan Perundang-Undangan:}

Undang-Undang Dasar 1945

Kitab Undang-Undang Hukum Perdata

Undang-Undang Nomor 8 Tahun 1999 Tentang Perlindungan Konsumen

Peraturan Pemerintah Republik Indonesia Nomor 58 Tahun 2001 Tentang Pembinaan dan Pengawasan Penyelenggaraan Perlindungan Konsumen.

\section{Sumber Lain}

David Tobing, Konsumen dan Klausula Baku, http://bpkn.go.id/uoloads/documents/6a c89beeea3f0dc87095541b652395208ebd4dc.pdf 